\title{
Water balance changes in the tropical rainforest with intensive forest management system
}

\section{Hatma Suryatmojo ${ }^{a c^{*}}$, Masamitsu Fujimoto ${ }^{b}$, Yosuke Yamakawa ${ }^{c}$, Ken'ichiro Kosugi ${ }^{c}$, Takahisa Mizuyama ${ }^{\mathrm{c}}$}

${ }^{a}$ Faculty of Forestry, Gadjah Mada University, Yogyakarta, Indonesia

${ }^{b}$ Department of Civil Engineering, Ritsumeikan University, Japan

${ }^{c}$ Graduate School of Agriculture, Kyoto University, Japan

Received: July 12, 2013 / Accepted: September 25, 2013

\begin{abstract}
Understanding the water balance changes in the forested area is important for managing the sustainability of water resources and anticipating potential disturbance caused by the implementation of a particular forest management system. This study was conducted in a natural tropical rainforest of Central Kalimantan, Indonesia. The objective of this study is to determine the water balance changes in the tropical rainforest under Intensive Forest Management System (IFMS) using a Thornthwaite Mather Water Balance (TMWB) model. The TMWB model calculates the water balance based on long-term average monthly precipitation, potential evapotranspiration, and combined latitudes, soil properties, and vegetation characteristics. The results found a good agreement between the predicted and observed monthly streamflows both in the natural forest and treated forest. In the natural forest found the runoff coefficient is o.5. It is assumed that $50 \%$ of the surplus water is actually available as streamflow in any given month, and the rest become detention water to supply soil moisture and ground water. It is also assumed that $50 \%$ of detention water is available as streamflow in the next month. 1-year after IFMS treatment, the runoff coefficient increased to o.6. Canopy cover reduction in the treated forest has reduced the annual evapotranspiration approximately in $45.3 \%$, while the annual runoff has increased approximately in $33.7 \%$ from natural forest.

The overall results of calculations using the the TMWB method indicated that the water balance status and runoff are not experiencing the problems leading to water deficit under natural tropical forest conditions. These results suggest that in the forested area, a strong relationship exists among rainfall, evapotranspiration, and runoff production. Surface disturbances, land-use changes, and reductions in canopy cover potentially impact the water balance-in particular, they influence evapotranspiration and infiltration processes that reduce evapotranspiration and increase runoff.
\end{abstract}

Keywords: tropical forest; water balance; evapotranspiration; runoff; canopy cover; surface disturbance.

\section{Introduction}

Tropical rain forests are among the most important biomes because of their high levels of primary productivity, and water and energy exchange with the atmosphere. Tropical rain forests are also a major source of global land surface evaporation [1] and have profound influences on global and regional climates, as well as on hydrological cycles $[2,3,4,5]$. Evapotranspiration in tropical rain forests is an important hydrological subject not only with regard to water resources and water availability for irrigation at the local level, but in terms of regional and global-scale water cycle studies [4]. In the humid tropics, climate change may drastically alter hydrological regimes, in addition to the altered rainfall patterns and land cover transformations occurring mainly as a result of forest conversion [6]. Consequently, such anthropogenic alterations may further accelerate global climate changes.

However, the water balance of Southeast Asian tropical rain forests is largely uncertain, and field studies on the exchange of water between Southeast Asian tropical rain forests and the atmosphere have been poorly documented compared with studies performed in Amazonian tropical rain forests [5]. To understand hydrological responses to catchment changes, determining the water balance and related variables is essential. The main components of the water budget in terms of runoff and evapotranspiration (Et) always use indicators for analyzing watershed conditions and describing watershed ecosystem functions. The water balance, as calculated for a single soil profile or for an entire watershed, refers to the balance between incoming water by precipitation and outgoing water from evapotranspiration, groundwater recharge, and streamflow. Several possible methods to calculate water balance have been developed, but these depend on available baseline data such as meteorology, vegetation structure, soil water characteristics, and stream gauge data in the catchment, as well as several physical characteristics.

Thornthwaite [7] proposed an empirical method to estimate evapotranspiration from mean temperature data. The method was modified by Thornthwaite and Mather [8] to make it more applicable to a wide range of soils and vegetation. The Thornthwaite and Mather [8] procedure calculates the water balance for the root zone. The technique has been successfully applied to water balances for whole watersheds and in calculations of recharge to groundwater $[9,10,11]$. In applying the TMWB procedure for a watershed, not all water leaving the root zone is immediately available for streamflow. Therefore, monthly streamflow is not well predicted, unless a certain portion of the runoff is carried over from 1 month to the next. The TMWB assumes that $50 \%$ of the surplus water is actually available as streamflow in any month.

The TMWB model offers a method to predict the hydrological processes of an entire watershed; in particular, it estimates evapotranspiration, water detention, water deficit, surplus water available for runoff, and runoff itself. This simple model is a useful tool for examining the transport of water and other materials in the scales of time and space that are of interest to geochemists and ecologists by combining several data for meteorology, physical factors, and vegetation characteristics.

The TMWB method has been generally accepted, particulary for water balances with dominant vegetation cover in the catchment. This technique uses long-term average monthly rainfall and average potential evapotranspiration, along with combined latitude and soil and vegetation characteristics. The last two factors are combined in the water-holding capacity (WHC) of the 
root zone. The method is applicable in those areas that are poorly monitored and can predict seasonal trends in rainfall, evapotranspiration, surplus or deficit in soil moisture, and runoff potential.

The objective of this chapter is to determine the water balance changes in the tropical rainforest under Intensive Forest Management System (IFMS) using a TMWB model. Understanding the water balance changes in tropical rain forests is crucial to the effective management of water resources in these managed forests.

\section{Methods}

\subsection{Study site}

The study was conducted in a tropical rainforest at the Bukit Baka Experimental Catchments, which are located in the headwater region of the Katingan watershed in Central Kalimantan. Two experimental catchment were used to calibrate the model, an natural catchment (no ha) (natural forest) and treated catchment (149 ha) with IFMS treatment (treated forest). The treated catchment was forest that had been selectively logged and 1-yearold line planted (Figure 1).

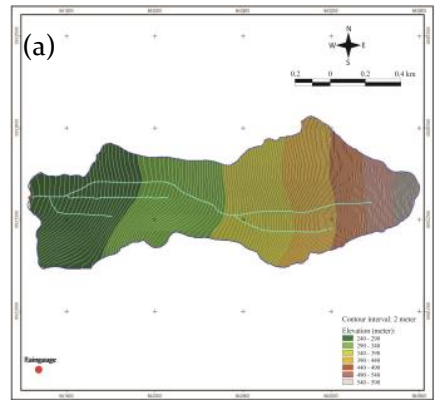

Figure 1 Experimental catchments. catchment.

\subsection{IFMS}

Traditional forest management in Indonesia consisted of the Indonesian selective cutting and replanting system (TPTI). The TPTI system conducts replanting in open forest areas including the log-landing areas, logging-road buffers and ex-cutting areas. Forest growth depends on the growth of natural regeneration. In the harvesting periods that followed TPTI, forest poroductivity was found to decrease over the first harvesting period. It has been shown that TPTI does not succeed in restoring forest potency in the harvesting periods that follow (Sianturi and Kanninen, 2005). To achieve sustainable forest management and maintain forest productivity, the management of tropical Indonesian rainforests then changed to an Intensive Forest Management System (IFMS), which was implemented officially in 2002. The main activities are timber harvesting using a selective logging method and forest rehabilitation with intensive line planting. Timber harvesting involves logging road construction, selective tree cutting, log skidding on skid trails, log hauling to log yards, and transportation of logs.

In the IFMS phase of timber harvesting, several additional logging road system controls are imposed to minimize the impact of logging roads. This includes the alignment of logging roads along the contour and proper drainage for road surface runoff. Selective logging is carried out by the typical current commercial logging practices with cutting regimes of $40 \mathrm{~cm}$ diameter at breast height $(\mathrm{DBH})$ for commercial dipterocarp and non-dipterocarp timber.

The IFMS phase after selective logging is forest rehabilitation with intensive line planting. Intensive line planting involves line clearing and line rehabilitation.
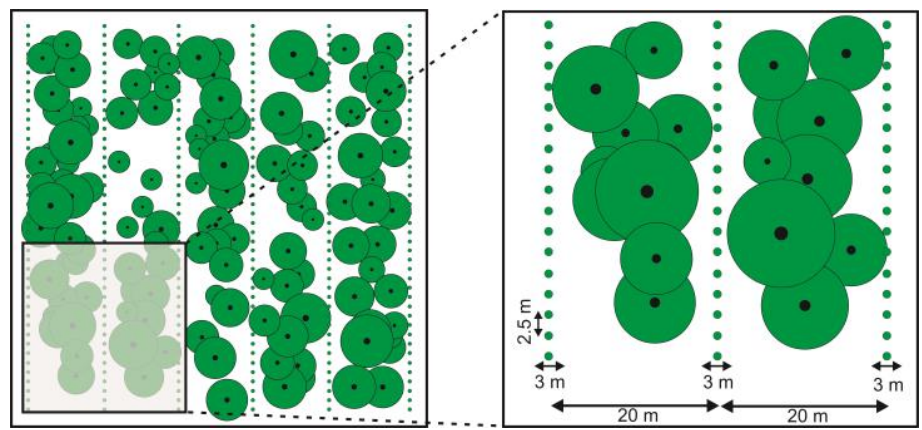

Figure 2 Canopy cover in the IFMS, after selective logging and intensive line planting.

About $15 \%-20 \%$ of the forest area is a clear-cut line to enrich the standing stock using an intensive strip-line planting system (Figure 2). About 200 seeds per hectare are typically planted, and the expected standing stock at the end of rotation (30 years) is approximately $400 \mathrm{~m} 3$ per hectare, assuming 160 trees per hectare with an average diameter of $50 \mathrm{~cm}$ (or $2.5 \mathrm{~m}^{3}$ per tree) [12].

\subsection{TMWB Model}

The method uses air temperature as an index of the energy available for evapotranspiration, assuming that air temperature is correlated with the integrated effects of net radiation and additional controls such as evapotranspiration and that available energy is shared in fixed proportions between heating the atmosphere and evapotranspiration. Thornthwaite and Mather [9] assumed that $50 \%$ of the surplus water is actually available as streamflow in any given month. For a small watershed in New Jersey, $75 \%$ of the total runoff was assumed to be carried over to the next month, and good agreement was found between the predicted and observed monthly streamflows [13, 14].

This method has been tested using measured runoff in the Rio Macho basin in Costa Rica, and the results indicated that this method can be satisfactorily applied to estimate mean monthly streamflow [15]. The TMWB method is useful for description, classification, management, and research [16].

The empirical equation developed by Thornthwaite, which relates the evaporation to mean air temperature is

$$
P E=16\left(10 \frac{T}{I}\right)^{a} \text {, }
$$

where $P E$ is the monthly potential evapotranspiration, $T$ is the monthly mean air temperature $\left({ }^{\circ} \mathrm{C}\right)$; I is a heat index for the station, which is the sum of 12 monthly heat indices $\mathrm{i}$ given by $\mathrm{i}=$ $(\mathrm{T} / 5)^{1.514}$, and a is a cubic function of $I$.

This method of computing the monthly water balance was revised and sumarized by Thornthwaite and Mather [9]. To determine the water balance at a site, the following specific information is necessary:

(a) latitude,

(b) mean monthly air temperature,

(c) monthly precipitation,

(d) runoff conversion coefficient,

(e) information of the WHC for soil at the depth for which the balance is to be computed.

Temporally varying inputs are monthly rainfall $(P)$ and potential evapotranspiration $\left(P E_{t}\right)$ in millimeters. Field soil moisture capacity $(F S M C)$ varies as a function of soil texture and plant rooting depth (estimated from general information on vegetation type), which are used for calculating the water storage (ST). Accumulated potential water loss $(A P W L)$ is the sum of negative values from the difference $P-P E_{t}$, accumulated from 1 month to 
the next over a 1-year period. Soil moisture has a maximum value equal to ST. The moisture status of the soils depends on the $A P W L$, which is calculated by two different methods depending on whether the potential evaporation is greater than or less than the cumulative precipitation [14].

For months when the potential evapotranspiration is in excess of the precipitation, the $A P W L$ is incrementally calculated from the differences in potential evapotranspiration $\left(\Sigma P E_{t}\right)$ and precipitation $(\Sigma P)$,

$$
A P W L_{t}=A P W L_{t}-\Delta_{t}+\left(\sum P E_{t}-\Sigma P\right)
$$

where $A P W L_{t}$ is the accumulated potential water loss at time $\mathrm{t}$ $(\mathrm{mm}), A P W L_{t}-\Delta t$ is the accumulated potential water loss at time $\mathrm{t}$ - $\Delta t$ (i.e., previous month; $\mathrm{mm}$ ), $\Sigma P E t$ is cummulative evapotranspiration over time period $\Delta t(\mathrm{~mm})$, and $\Sigma P$ is the cumulative precipitation over the time period $\Delta t(\mathrm{~mm})$.

The relationship between $A P W L$ and the amount of water stored in the root zone is expressed as

$$
S T_{t}=S T_{f}\left[\exp \left(\frac{-A P W L_{t}}{S T_{f}}\right)\right]
$$

where $S T_{t}$ is the available water stored in the root zone at time $t$ $(\mathrm{mm})$ and $S T_{f}$ is the available water storage at field capacity in the root zone $(\mathrm{mm})$.

Months when potential evaporation is less than the precipitation $(P)$, the storage in the soil is calculated as the difference between the potential evapotranspiration and measured precipitation:

$$
S T_{t}=S T_{t}-\Delta_{t}+\left(-\Sigma P-\Sigma P E_{t}\right)
$$

If the storage $S T_{t}$ at time $\mathrm{t}$ is higher than field capacity, then the percolation $\left(R e c h_{t}\right)$ is simply calculated as

$$
\operatorname{Rech}_{t}=S T_{t}-S T_{t}-\Delta_{t}+\Sigma P-\Sigma P E_{t}
$$

and the $A P W L$ is set equal to zero. If, on the other hand, the moisture content in the root zone does not reach field capacity, then the APWL can be found by combining equations (3) and (4), and no percolation will occur in this situation:

$$
A P W L_{t}=-S T_{t} \ln \left[\frac{\left(S T_{t-\Delta t}+\Sigma P-\Sigma P E_{t}\right)}{S T_{f}}\right]
$$

Temporally varying inputs are monthly precipitation $(P)$ and potential evapotranspiration $\left(P E_{t}\right)$ in millimeters. FSMC varies as a function of soil texture and plant rooting depth (estimated from general information on vegetation type). $A P W L$ is the sum of negative values from the difference $P-P E_{t}$, accumulated from 1 month to the next. Soil moisture, the available water stored in the root zone (ST), has a maximum value equal to FSMC and decreases as a function of $A P W L$ according to equation (2). From these data, one calculates the actual evapotranspiration $\left(A E_{t}\right)$.

The above information and calculation are used to derive total water available for runoff (TARO) as surplus water. Runoff $(R O)$ is total flow with some detention to account for temporary storage, i.e., the surplus soil moisture. For a particular month, $R O$ is some fraction $(k<1)$ of TARO for that month, as calibrated for the system. Water detention $(D E T)$ is detention water for the groundwater supply. The DET is equal to the remaining portion of TARO and represents temporary water storage as surface ponding, a raised groundwater table, and oversaturation of the soil.
Thornthwaite and Mather [8, 9] suggested that for large watersheds, $\mathrm{k}$ should be about 0.5 and should increase for smaller watersheds, steep topography, and shallow soils.

\subsection{Field observation}

Meteorological data used were from three manual raingauges measured since 2001 and one unit automatic weather station installed in 2009. Meteorological data of monthly rainfall and temperature were observed during 2001 to 2012.

Field observation in the experimental catchments was conducted in 2011. A Parshall flume and a water-level logger with a time interval of $15 \mathrm{~min}$ were installed at each catchment outlet. Streamflow observations were conducted from January to December 2011.

\section{Results and Discussion}

\subsection{Meteorological characteristics}

The available rain gauges provide an adequate coverage of elevation and topography. Monthly rainfall and average temperature are shown in Table 1 and the annual rainfall is given in Figure 3.

Table 1 Monthly rainfall and average temperature

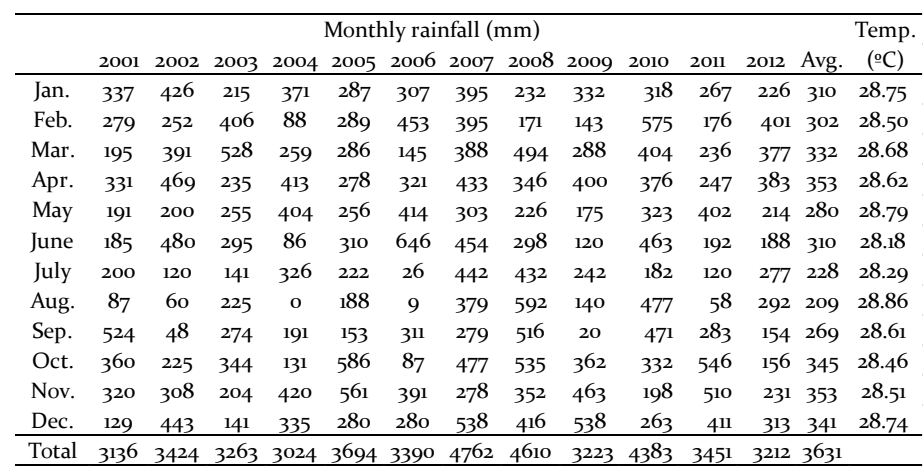

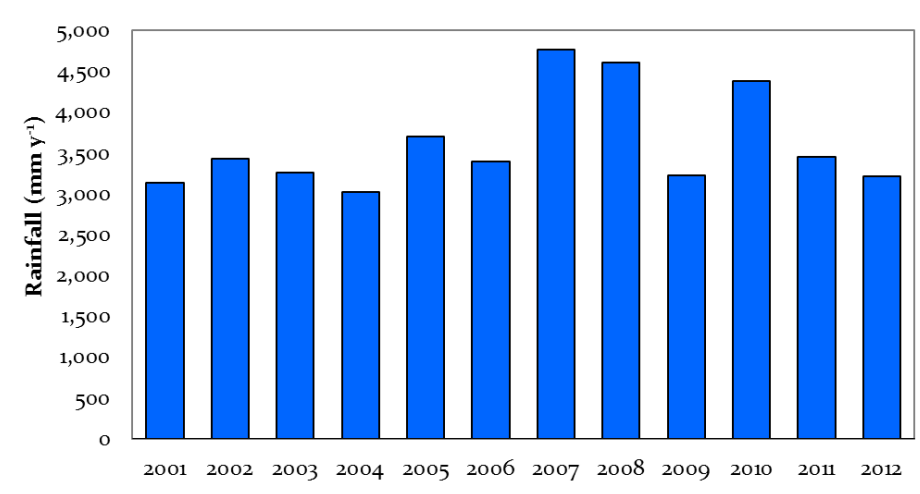

Figure 3 Annual rainfall from 2001 to 2012.

According to the forest climate classification system of Schmidt and Ferguson [17], the area is type A (very wet) tropical rain forest (monthly average rainfall $>100 \mathrm{~mm}$ ). The mean annual rainfall from 2001 to 2012 was $3631 \mathrm{~mm}$, with the highest average monthly precipitation $(353 \mathrm{~mm})$ occurring in November and the lowest average monthly precipitation $(209 \mathrm{~mm})$ occurring in August (Table 3.1). The number of rainy days varies from 95 to 112 days, and the mean annual temperature is $30^{\circ} \mathrm{C}-33^{\circ} \mathrm{C}$ at noon and $22^{\circ} \mathrm{C}-$ $28^{\circ} \mathrm{C}$ at night.

The FSMC is described as the WHC that varies as a function of soil texture and plant rooting depth (estimated from general information on vegetation type from the SBK company concession area). The estimated soil depth within the watershed was between 200 and $300 \mathrm{~cm}$. Soil texture was dominated by clay loam and the 
available water was $250 \mathrm{~mm} / \mathrm{month}$. The root zone depth average was $1.60 \mathrm{~m}$. A combination of available water and root zone depth produced a $W H C$ of $400 \mathrm{~mm}$.

\subsection{Canopy cover changes}

The IFMS changed the forest canopy cover. The profile of vegetation structure and composition was monitored in 1-hectare permanent sample plot (PSP) in each catchment. Selective logging and intensive line planting significantly decreased forest canopy cover by reducing the number of trees. Tree canopy cover conditions in the catchment area are shown in Figure 4.

(a)

(b)
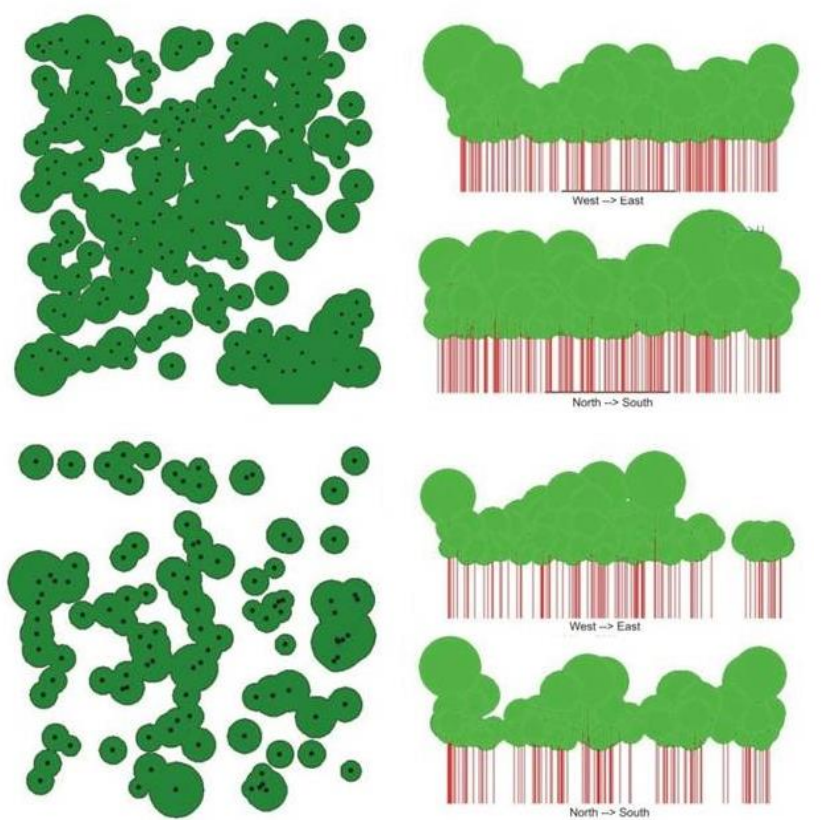

Horizontal projection

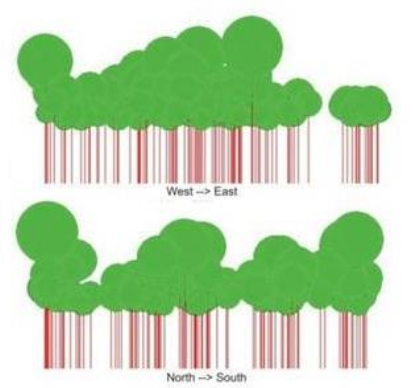

Vertical projection

Figure 4. Tree canopy cover in the PSP. (a) Natural forest. (b) Treated forest.

The percentage tree canopy cover was $80.1 \%$ in the natural forest (Figure 4a). Canopy cover decreased to $49.3 \%$ in the treated forest with IFMS (Figure 4b). Thus, IFMS has decreased the canopy cover by approximately $38.5 \%[18]$.

\subsection{Calibration of the runoff coefficient in the natural catchment}

The TMWB model requires only one calibration parameter, which can be termed the runoff coefficient $(k)$, used to estimate monthly runoff $(R O)$ and detention water $(D E T)$. Streamflow measured at the natural catchment in 2011 was used to calibrate between runoff observed with the stream gauge and the runoff calculated using the TMWB method. Several calibration values of $k$ were analyzed to find the highest coefficient correlation between observed runoff from stream gauge and calculated runoff using TMWB method. The highest correlation coefficient of 0.82 was found for a $k$ value of 0.5. Calculated TMWB values in 2011 is shown in Table 2.

Figure 5 shows the agreement between observed and calculated runoff $(R O)$ for the natural catchment. The assumption was made that $50 \%$ of the total water available for runoff (TARO) or surplus water in the present month will become runoff and the rest will become detention water $(50 \%$ of the detention water will flow out in the next month).
Table 2 Monthly water balance in the natural catchment

\begin{tabular}{lrrrrrrrrrrrrr}
\hline & Jan. & Feb. & Mar. & Apr. & May & June & July & Aug. & Sep. & Oct. & Nov. & Dec. Total \\
\hline P & 267.4 & 176.2 & 236.4 & 247.5 & 401.9 & 192.1 & 120.4 & 58.4 & 283.4 & 546.0 & 510.3 & 411.2 & 3451.3 \\
PEt & 111.6 & 114.8 & 109.0 & 109.2 & 109.5 & 103.9 & 111.8 & 105.9 & 107.4 & 109.6 & 102.9 & 100.7 & \\
APWL & 0.0 & 0.0 & 0.0 & 0.0 & 0.0 & 0.0 & 0.0 & -47.5 & 0.0 & 0.0 & 0.0 & 0.0 & \\
ST & 400.0 & 400.0 & 400.0 & 400.0 & 400.0 & 400.0 & 400.0 & 355.2 & 400.0 & 400.0 & 400.0 & 400.0 & \\
AEt & 111.6 & 114.8 & 109.0 & 109.2 & 109.5 & 103.9 & 111.8 & 103.2 & 107.4 & 109.6 & 102.9 & 100.7 & 1293.6 \\
DEF & 0.0 & 0.0 & 0.0 & 0.0 & 0.0 & 0.0 & 0.0 & 2.7 & 0.0 & 0.0 & 0.0 & 0.0 & \\
TARO & 155.8 & 61.4 & 127.4 & 138.3 & 292.4 & 88.2 & 8.7 & 0.0 & 131.2 & 436.4 & 407.4 & 310.6 & 2157.7 \\
RO & 93.4 & 69.6 & 79.1 & 101.0 & 180.8 & 117.2 & 26.4 & 2.2 & 65.6 & 251.0 & 312.8 & 257.1 & 1556.1 \\
DET & 77.9 & 30.7 & 63.7 & 69.1 & 146.2 & 44.1 & 4.3 & 0.0 & 65.6 & 218.2 & 203.7 & 155.3 & \\
\hline
\end{tabular}

Note: all values are prorated per unit area and expressed as millimeters of water flux

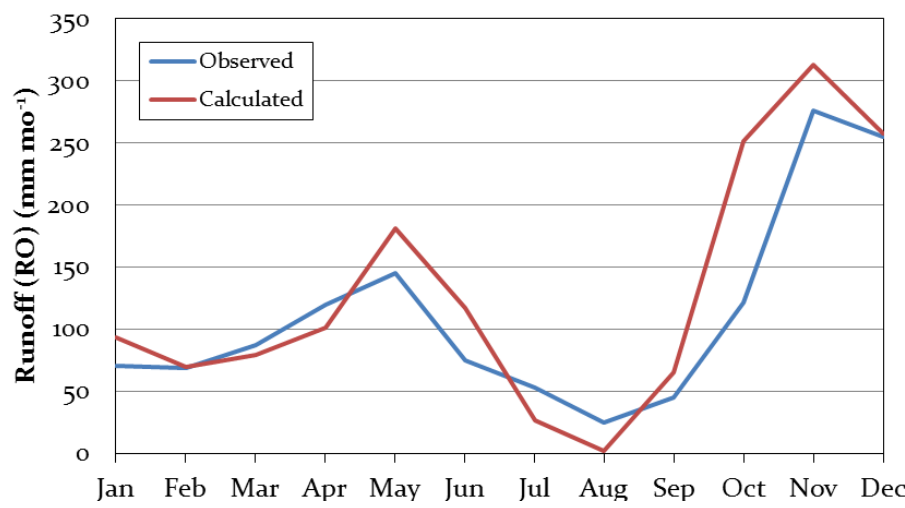

Figure 5 Monthly runoff comparisons between observed and calculated using TMWB model in the natural forest.

The calculated water balance underestimated runoff during the dry season and overestimated runoff during the rainy season compared to the perennial stream in the observed natural catchment (Figure 5). These errors resulted because surface soil moisture storage $(S T)$ did not remain constant over these periods.

\subsection{Calibration of the runoff coefficient in the treated catchment}

Streamflow measured at the treated catchment with IFMS in 2011 was used to calibrate between runoff observed with the stream gauge and the runoff calculated using the TMWB method. The highest correlation coefficient of 0.81 was found for a $k$ value of o.6. Calculated TMWB values for treated catchment in 2011 is shown in Table 3.

Table 3 Monthly water balance in the treated catchment

\begin{tabular}{lrrrrrrrrrrrrr}
\hline & \multicolumn{1}{c}{ Jan. } & Feb. & \multicolumn{1}{c}{ Mar. } & Apr. & May & June & July & Aug. & Sep. & Oct. & Nov. & Dec. & Total \\
\hline P & 267.4 & 176.2 & 236.4 & 247.5 & 401.9 & 192.1 & 120.4 & 58.4 & 283.4 & 546.0 & 510.3 & 411.2 & 3451.3 \\
PEt & 62.5 & 64.3 & 61.0 & 61.2 & 61.3 & 58.2 & 62.6 & 59.3 & 60.1 & 61.4 & 57.6 & 56.4 & \\
APWL & 0.0 & 0.0 & o.o & 0.0 & 0.0 & 0.0 & 0.0 & -48.5 & 0.0 & 0.0 & 0.0 & 0.0 & \\
ST & 4 O0o.0 & 400.0 & 400.0 & 400.0 & 400.0 & 400.0 & 400.0 & 354.3 & 400.0 & 400.0 & 400.0 & 400.0 & \\
AEt & 62.5 & 64.3 & 61.0 & 61.2 & 61.3 & 58.2 & 62.6 & 56.5 & 60.1 & 61.4 & 57.6 & 56.4 & 723.1 \\
DEF & 0.0 & 0.0 & 0.0 & 0.0 & 0.0 & 0.0 & 0.0 & 2.8 & 0.0 & 0.0 & 0.0 & 0.0 & \\
TARO & 139.5 & 59.7 & 178.8 & 270.4 & 330.3 & 90.6 & 71.7 & 0.0 & 42.2 & 327.6 & 411.4 & 343.8 & 2266.0 \\
RO & 99.14 & 63.71 & 119.20 & 198.02 & 252.25 & 120.43 & 61.16 & 14.34 & 25.30 & 205.00 & 312.36 & 288.58 & 1759.5 \\
DET & 55.79 & 23.88 & 71.51 & 108.17 & 132.11 & 36.25 & 28.69 & 0.00 & 16.86 & 131.04 & 164.56 & 137.53 & \\
\hline
\end{tabular}

The comparison between calculated runoff from Table 3 and observed runoff from stream gauge in the treated catchment is shown in Figure 6. 


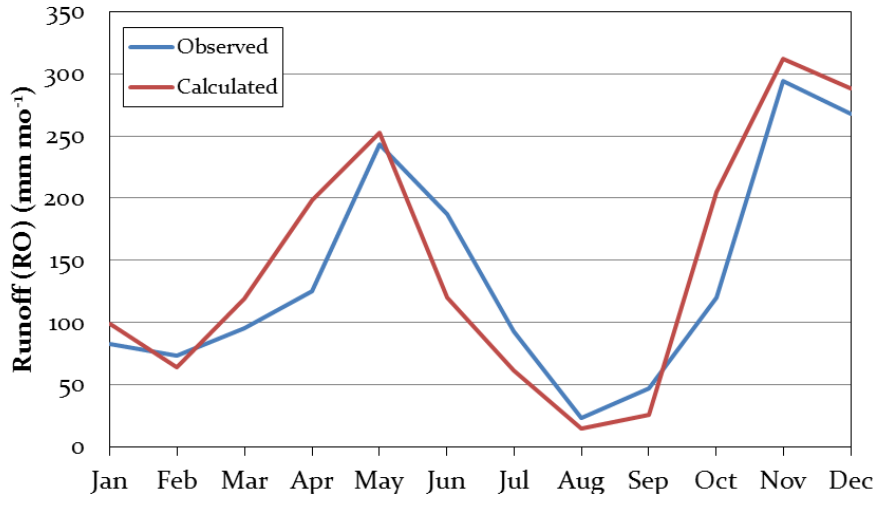

Figure 6 Monthly runoff comparisons between observed and calculated using TMWB model in the treated forest.

Figure 6 shows in the treated catchment with IFMS increased the runoff flow in the stream channel. IFMS decreased the canopy cover by $38.5 \%$ of natural catchment and lead to the formation of large canopy openings, resulting from tree felling, skid trails and haul roads constructions [18]. A large open canopy in the treated catchment reduced the forest interception and transpiration, increasing net rainfall reaching the forest floor and may increasing the soil moisture.

\subsection{Monthly water balance}

Figure 7 shows the average monthly water balance at the study site from 2001 to 2012, illustrating expected relationships among rainfall $(P)$, evapotranspiration $\left(A E_{t}\right)$, and runoff $(R O)$. Using the fitted coefficient $k$ (o.5), the TMWB value for natural forest in the study site was calculated for the 2001-2012 period. The calculated water balance is shown in Figure $7 \mathrm{a}$. The fitted coefficient $k$ for treated forest is 0.6 , and the water balance shown in Figure $7 \mathrm{~b}$.

Figure 7 shows that natural forest produced higher monthly evapotranspiration and lower monthly runoff than that in the treated forest. Lower canopy cover density (Figure 4) in the treated forest accelerates the amount of net rainfall in the forest floor. Surface disturbance from logging and line planting activities potentially reduced the surface retention and infiltration capacity, which will produce larger surface runoff than that in the natural forest. Figure 7 also indicate that the water detention (water surplus - runoff) in the natural forest is larger than that in the treated forest. Water detention is important for groundwater supply.

It shows that runoff occurs throughout the years with minimum runoff taking place mainly from July to September, and the maximum runoff occurring from November to January. The dry season is dominated by high potential evapotranspiration $\left(P E_{t}\right)$, which draws surface soil moisture storage $(S T)$ down so that from July to September, the runoff is at a minimum near zero. Water surplus is defined as total water available for runoff (TARO). This water surplus then used to produce both runoff $(R O)$ and detention water $(D E T)$.

Even though the study site was classified as a tropical rain forest climate, a dynamic variation in the rainfall-runoff response still occurred throughout the years. The dry season took place largely from June to October, while the rainy season occurred predominantly from November to May with two peaks in rainfall amount at the beginning and end of the rainy season. Transitions between the dry and rainy seasons were so sharp that soil moisture storage $(S T)$ was a significant factor in total water available for runoff (TARO). The reduced $S T$ caused the TARO to be utilized for ST first, with the remaining being used as runoff.
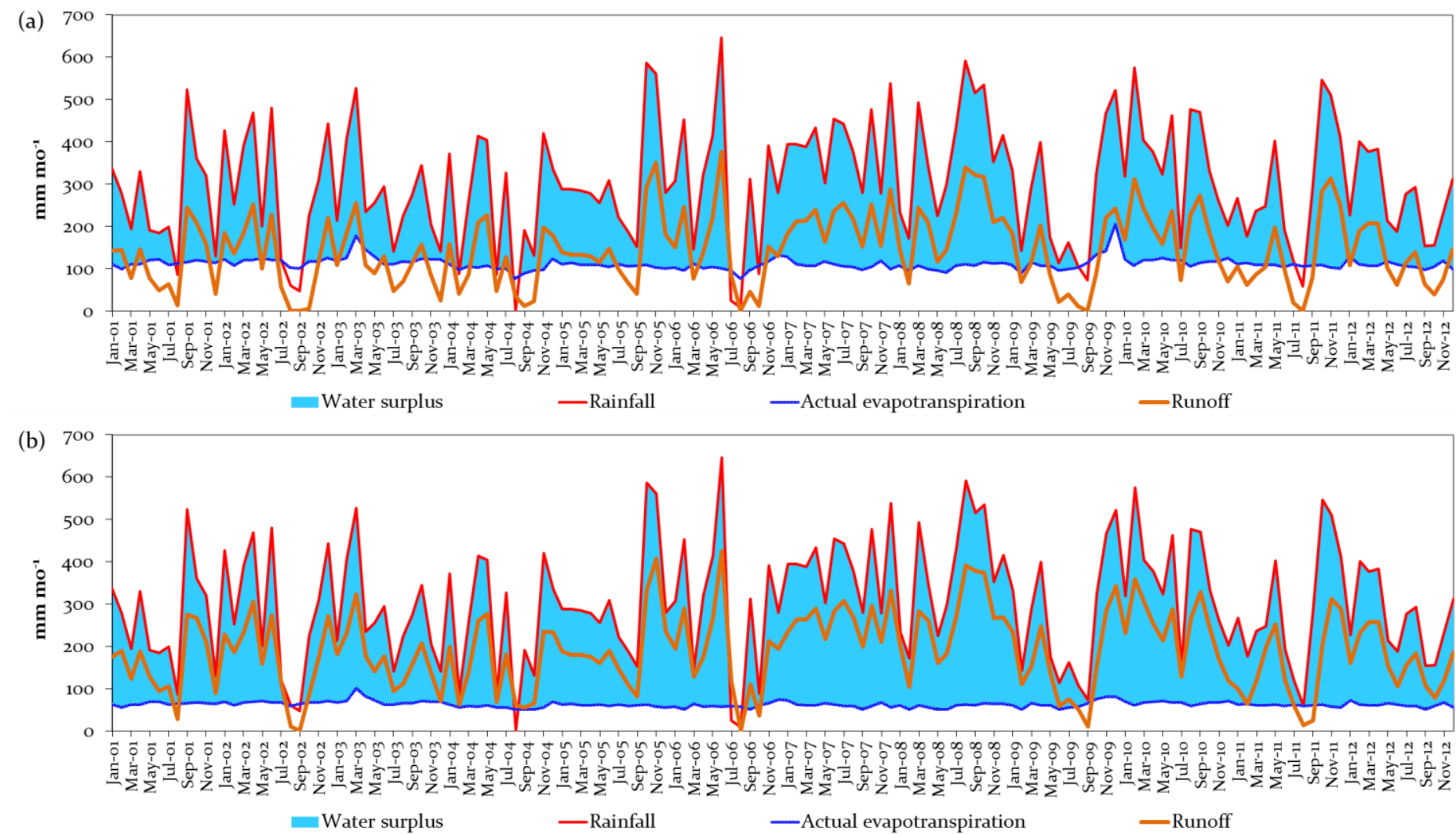

Figure 7 Time series of the long-term monthly water balance from 2001 to 2012. (a) Natural catchment. (b) Treated catchment. 


\subsection{Changes in monthly evapotranspiration}

During the monitoring period from 2001 to 2012, the variation data from monthly rainfall and calculated evapotranspiration $\left(A E_{t}\right)$ were used to determine the water balance characteristics at the study site. Figure 8 shows the evapotranspiration reductions between natural forest and treated forest.

The monthly evapotranspiration in the natural forest for a 12year period ranged from 81 to $151 \mathrm{~mm} \mathrm{m-1}$ (mean $=109.8 \mathrm{~mm} \mathrm{~m}-$ 1). Annual evapotranspiration ranged from 1217 to $1519 \mathrm{~mm}$. Annual evapotranspiration was similar to that found in a previous study in Bukit Tarek, Malaysia, which found that evapotranspiration ranged from 1243 to $1605 \mathrm{~mm}$ [4]. Evapotranspiration, measured using a 8o-m-tall canopy crane in Lambir Hills National Park, Sarawak Malaysia, resulted in an annual evapotranspiration (sum of evaporation and interception) of $1545 \mathrm{~mm}$, accounting for approximately $72 \%$ of the total rainfall [5].

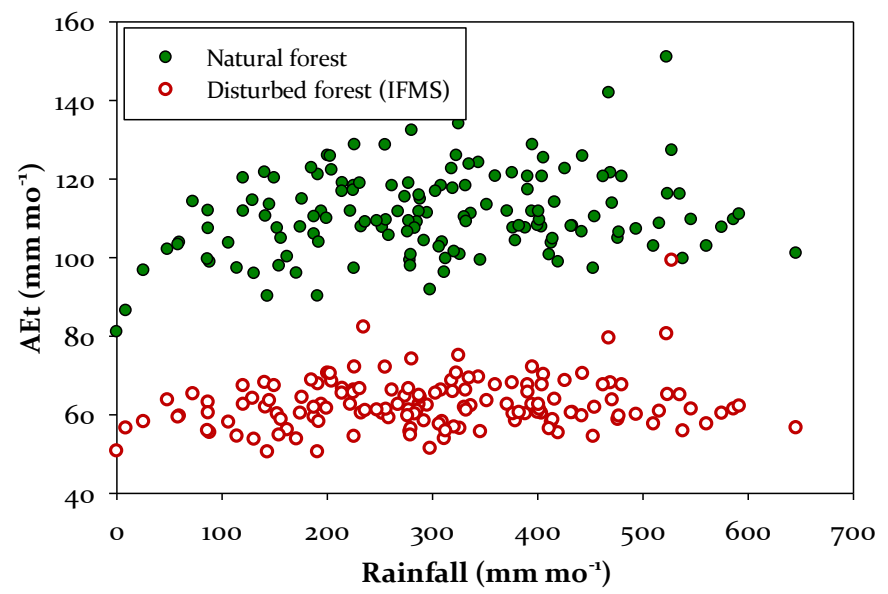

Figure 8 Evapotranspiration reductions between natural forest and treated forest.

Selective logging and clear line for intensive planting reduced the canopy cover and interception. This change has reduced the evapotranspiration from forest canopy. For a 12-year period of treated forest, the $A E_{t}$ ranged from 50 to $99 \mathrm{~mm} \mathrm{mo}^{-1}$ (mean = $62.6 \mathrm{~mm} \mathrm{mo}^{-1}$ ). Annual evapotranspiration ranged from 687 to $850 \mathrm{~mm}$.

\subsection{Changes in monthly runoff}

Interannual and monthly variations in rainfall were used to directly examine the relationship between rainfall and runoff. Calculated runoff is not strictly surface runoff, but includes water removal for use outside the watershed as well as subsurface flow and groundwater flow. In the water balance concept, it is instructive to consider how antroppogenic activity may alter the natural water flow. There are two aspects of altered flow. The first is the reduction in total flow by water removal from the system. The second is the alteration of the shape of the natural hydrograph by water capture during periods of high natural flow and release during periods of low or no natural flow [19].

Figure 9 shows a linear relationship between monthly rainfall and runoff for natural forest and treated forest with IFMS treatment. Figure 9 shows in the natural forest condition, $47.6 \%$ of monthly rainfall become runoff, while in the treated forest with IFMS, $62.4 \%$ of monthly rainfall become runoff. The high canopy cover density in untreated areas controlled the net precipitation by canopy interception and evapotranspiration.

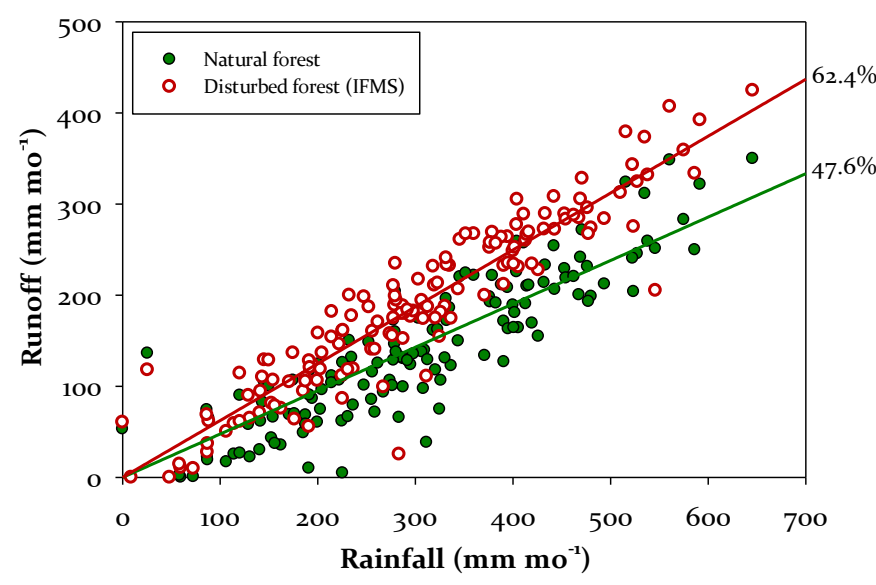

Figure 9 Relationship between monthly rainfall and runoff in the natural forest and treated forest with IFMS.

\subsection{Annual water balance changes}

A change in land use in a catchment may lead to changes in its water balance. The response time of stream flow is generally determined by climate (mostly rainfall), vegetation characteristics, catchment properties, and vegetation management practices [20]. The forest canopy serves as a barrier against precipitation reaching the ground. Canopy cover reduction led to lower evapotranspiration and higher net precipitation in the treated forest. Selective logging activity using tractors has opened and destroyed approximately $4-6 \%$ of the soil surface of the forested area by creating skid trails and a further $60-75 \%$ by pulling logs using a tractor winch. Manual land clearing for intensive line planting has opened approximately $15-20 \%$ of the forested area in the study catchment. Forest disturbances have changes the water balance significantly. The annual water balance changes between natural forest and treated forest is shown in Table 4 .

Table 4 Annual water balance changes

\begin{tabular}{lcc}
\hline & Natural forest & Treated forest \\
\hline Evapotranspiration* & $28-47 \%$ & $15-26 \%$ \\
Runoff* & $40-55 \%$ & $59-68 \%$ \\
\hline *Percentage of annual rainfall &
\end{tabular}

Table 4 shows the canopy cover reduction in the treated forest has decreased the annual evapotranspiration approximately in $45.3 \%$ of annual evapotranspiration in the natural forest. Annual runoff in the treated forest has increased approximately in $33.7 \%$ of annual runoff in natural forest.

Logged forest had less canopy cover, compacted soils, and low infiltration capacities. Consequently, these conditions creating quick runoff responses that was dominated by surface flow and increased the percentage of rainfall to runoff in the catchment. The change of forest cover and destruction of soils are the dominant factors impacting runoff responses.

\section{Conclusions}

The results found a good agreement between the predicted and observed monthly water balance both in the natural forest and treated forest. Runoff coefficient in the natural forest is 0.5. It is assumed that $50 \%$ of the surplus water is actually available as streamflow in any given month, and the rest become detention water to supply soil moisture and ground water. It is also assumed that $50 \%$ of detention water is available as streamflow in the next month. 1-year after IFMS treatment, the runoff coefficient increased to o.6.

Canopy cover reduction in the treated forest has reduced the annual evapotranspiration approximately in $45.3 \%$, while the 
annual runoff has increased approximately in $33.7 \%$ from natural forest.

Surface disturbance, land-use changes, and reductions in canopy cover potentially impact the water balance-in particular, they influence evapotranspiration and infiltration processes that reduce evapotranspiration and increase runoff.

In order to achieve the sustainable forest management system, the forest management practices should consider and attempt to minimize forest disturbance during IFMS treatments. Adequate protection of the forest floor with strict control over logging activities might reduce the impacts on water balance.

\section{References}

[1] Choudhury, B., DiGirolamo, N.E., Susskind, J., Darnell, W.L., Gupta, S.K., Asrar, G. A biophysical process-based estimate of global land surface evaporation using satellite and ancillary data, II. Regional and global patterns of seasonal and annual variations. J. Hydrol., 1998; 205:186-204.

[2] Lean, J., Warrilow, D.A. Simulation of the regional climatic impact of Amazonian deforestation. Nature, 1989; 342:411-413.

[3] Nobre, C.A., Sellers, P.J., Shukla, J. Amazonian deforestation and regional climate change. J. Climate, 1991; 4:957-988.

[4] Noguchi, S., Abdul Rahim, NIK., Shamsuddin, S.A., Tani, M., Sammori, T. Evapotranspiration estimates of tropical rain forest, Bukit Tarek experimental watershed in Peninsular Malaysia, using the short-time period water-budget method. J. Japan Soc. Hydrol. \& Water Resour., 2004; 17(5):482-492.

[5] Kumagai, T., Saitoh. T.M., Sato, Y., Takahashi, H., Manfroi, O.J., Morooka, T., Kuraji, K., Suzuki, M., Yasunari, T., Komatsu, H. Annual water balance and seasonality of evapotranspiration in a Bornean tropical rainforest. Journal of Agricultural and Forest Meteorology., 2005; 128:81-92.

[6] Bruijnzeel, L.A. Predicting the hydrological impacts of land cover transformation in the humid tropics: the need for integrated research. In: Gash, J.H.C., Nobre, C.A., Roberts, J.M., Victoria, R.L. (Eds.), Amazonian deforestation and climate. John Wiley \& Sons, New York, pp. 15-55, 1996.

[7] Thornthwaite, C.W. A new and improved classification of climates. Geography Reviews., 1948; 38 (1), 55-94.

[8] Thornthwaite, C.W. and Mather, J.R. The Water Balance. Lab. Climatol. Publ. 8, Centerton, New Jersey. 1955.

[9] Thornthwaite, C.W. and Mather, J.R. Instructions and Tables for Computing Potential Evapotranspiration and the Water Balance. Publ. 10, New Jersey. 1957.

[10] Alley, W.M. On the treatment of evapotranspiration, soil moisture accounting and aquifer recharge in monthly water balance models. Water Resour. Res., 1984; 20:1137-1149.

[11] Peranginangin, N.; Sakthivadivel, R.; Scott, N.R.; Kendy, E.; Steenhuis, T. Water accounting for conjuctive groundwater/surface water management: case of the Singkarak-Omnilin River basin, Indonesia. Journal of Hydrology, 2004; 292:1-22.

[12] Na'iem, M. and Faridah, E. Model of Intensive Enrichment Planting (TPTII). in : A. Rimbawanto (Eds.), Silviculture Systems of Indonesia's Dipterocarps Forest Management A Lesson Learned. Faculty of Forestry Gadjah Mada University and ITTO. Technical Report: ITTO Project PD 41/oo Rev. 3 (F,M), pp. 25-36, 2006.

[13] Mather, J.R. Using computed stream flow in watershed analysis. Water Resour. Bull., 1981; 17:474-482.

[14] Steenhuis, T.S. and Van Der Molen, W.H. The ThornthwaiteMather Procedure as a Simple Engineering Method to Predict Recharge. Journal of Hydrology, 1986; 84:221-229.

[15] Calvo, J.C. An evaluation of Thornthwaite's water balance technique in predicting stream runoff in Costa Rica. Journal of Hydrological Sciences. 1986.

[16] Black, P.E. Watershed Hydrology, 2nd edition, CRC Press, Boca Raton, Florida. 408 pp. 1996.

[17] Schmidt, F.H., Ferguson, J.H.A. Rainfall types based on wet and dry period ratios for Indonesia with Western New Guinea. Verh. Djawatan Met. Dan Geofisik. Djakarta 42, 1951.

[18] Suryatmojo, H., Fujimoto, M., Kosugi, K., Mizuyama, T. Runoff characteristics at different forest cover catchments in a tropical
Indonesia rainforest. Proceedings of The IHP Symposium on Extreme Events "Meteorological, Hydrological and Tsunami Disaster: social Adaptation and Future". Kyoto University, Japan, , 2011, pp. 19-28.

[19] Fischer, D.T., Smith, S.V. and Churchill, R.R. Simulation a century of runoff across the Tomales watershed, Marin County, CA. Journal of Hydrology, 1996; 186:253-273.

[20]Alice E. Brown, Lu Zhang, Thomas A. McMahon, Andrew W. Western, and Robert A. Vertessy. A review of paired catchment studies for determining changes in water yield resulting from alterations in vegetation. Journal of Hydrology,2005; 310:28-61. 